\section{Variation in Physiological Biomarkers with Different Clostridium perfringens Isolate Infections in Balkhi Sheep}

\author{
Mumtaz Ali Khan', Sher Bahadar Khan², Shakoor Ahmad', Irshad Ahmad \\ Kashif Prince ${ }^{1 *}$, Ghazunfar Rashid ${ }^{1}$, Mahboob Ali ${ }^{1}$, Imdad Ullah Khan ${ }^{4}$, \\ Asad Ullah ${ }^{5}$, Naimat Ullah ${ }^{4}$, Muhammad Shoaib ${ }^{2}$ and Said Sajjad Ali Shah ${ }^{2}$ \\ ${ }^{1}$ University of Veterinary and Animal Sciences, Lahore \\ ${ }^{2}$ Department of Animal Health, The University of Agriculture, Peshawar \\ ${ }^{3}$ Instutute of Basic Medical Sciences, Khyber Medical University, Peshawar \\ ${ }^{4}$ Gomal College of Veterinary Sciences, Gomal University, D.I. Khan \\ ${ }^{5}$ College of Veterinary Sciences and Animal Husbandry, Abdul Wali Khan University, \\ Mardan
}

\begin{abstract}
A B S T R A C T
The objective of this study was to determine variations of different physiological biomarkers in Clostridium perfringens (CP) infections in Balkhi breed of sheep in Khyber Pakhtunkhwa, Pakistan. Study was conducted on 184 sheep suspected of having enterotoxemia and 107 sheep were identified to be infected with Clostridium perfringens. Genotypic Analysis of all isolates from infected sheep was performed. Results showed, $53.27 \%$ isolates showed infection of $C P$ type A, $10.28 \%$ of type $\mathrm{B}$ and $36.44 \%$ of type D. Animal infected with different serotypes (A, B, and C) were categorized into two groups healthy and diseased to compare the hematological and biochemical parameters. Hematobiochemical analysis indicated that mean erythrocyte count (RBC) and hemoglobin levels decreased while the mean leukocytes (WBC), platelets, packet cell volume (PCV) and total bilirubin levels increased significantly $(\mathrm{P}<0.05)$ in sheep infected with Clostridium perfringens type A. Sheep infected with Clostridium perfringens type $\mathrm{B}$ and type $\mathrm{D}$ showed significant $(\mathrm{P}<0.05)$ decreases in erythrocytes counts $(\mathrm{RBC})$ and hemoglobin levels while the mean WBC, platelets, packet cell volume, serum creatinine, bilirubin, liver enzymes, total, glucose and urea in blood significantly $(\mathrm{P}<0.05)$ increased. Fluctuations in mean erythrocyte counts (RBC), hemoglobin, PCV and total bilirubin were beyond the limits while others were within normal ranges in sheep infected with Clostridium perfringens type A. The total bilirubin, Liver enzymes, creatinine level, glucose and urea levels in blood were abnormal while others were within normal ranges in sheep infected with $C P$ type B and type D. by observing these changes it will be possible to diagnose disease at initial stages.
\end{abstract}
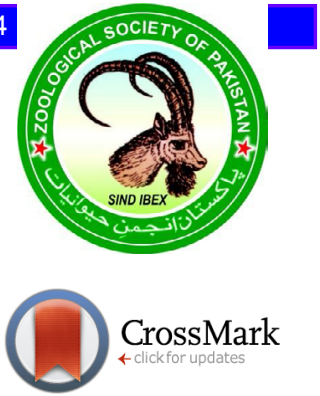

\section{INTRODUCTION}

$\mathrm{S}$ mall ruminants face various health challenges including Clostridium perfringens (CP) induced enterotoxemia. The sickness is primarily grouped into five types (A to E) based on distribution of four major toxins i.e. alpha, beta, epsilon and iota (Uzal et al., 2014). Type A causes yellow lamb disease, type B lamb dysentery; type C struck, type D pulpy kidney and type E enterotoxemia respectively (Uzal and Songer., 2008). There are three types of enterotoxemia per acute, acute and chronic forms (Fernandez and Uzal., 2003). The syndrome is a common and endemic illness in goats and sheep in Pakistan (Khan et al., 2008;

\footnotetext{
* Corresponding author: kashif_prince@live.com 0030-9923/2020/0006-2121 \$ 9.00/0

Copyright 2020 Zoological Society of Pakistan
}

Tahir et al., 2013). It is rod shape, spore forming, gram positive anaerobic microbe that causes disease in animals and humans, primarily through the production of one or any combination of the four toxin types listed above. Certain factors are thought to contribute to be critical in stimulating toxin gene expression, for example, sudden change in feed, over ingestion of grains and rich green feed (Javed et $a l ., 2009)$. During rainy season, access to rich green fields and high levels grain feeding regimens are considered as critical factor for this malady in small ruminants (Lewis, 2000). As of late polymerase chain response (PCR) is favored over other diagnosing strategies for the diagnosing of CP (Gkiourtzidis et al., 2001; Baums et al., 2004). $\mathrm{CP}$ toxins are absorbed by the small intestine, once in circulation; these toxins are disseminated throughout the host to target cells of numerous tissues, including liver, kidney, pulmonary, neurological, and intestinal epithelium 
(Ma et al., 2011). CP type D disease is characterized by changes in hematobiochemical parameters i.e. RBC, PCV, WBC, platelets, serum creatinine, blood glucose and urea levels (Nasir et al., 2013).

\section{MATERIALS AND METHODS}

\section{Geographical area}

This project was carried out in Khyber Pakhtunkhwa province, Pakistan from January to December 2016 in two different topographic regions; Swat (hilly) and Mardan (plain) districts. The Animal Ethical Committee approved this project via Ref. No. DAS/5121, dated: March 9, (2016).

\section{Sample collection}

The samples were obtained from cases brought to veterinary hospitals through convenient sampling. A total of 184 fecal samples were obtained from enterotoxaemia suspected Balkhi sheep. From which seven blood samples were collected from infected with each type of $\mathrm{CP}$ and twenty on from healthy as reference for biomarkers through convenient purposive sampling technique. These samples were collected from 6-12 months age Balkhi sheep having similar size and area. Healthy were only included which produced no growth on tryptose sulfite cycloserine agar media.

\section{Bacteriological examination}

Samples were collected with rectal swabs; these were placed in sterile air tight bottles and sent to the laboratory under $4^{\circ} \mathrm{C}$ (Nayel et al., 2013). The fecal samples were inoculated on tryptose sulfite cycloserine agar media (HiMedia Laboratories pvt Ltd. India) and incubated for 24 hours at $37^{\circ} \mathrm{C}$ in anaerobic jar with $\mathrm{CO}_{2}$ packs (Oxoid Ltd). Initially the isolates were identified through colony morphology and Gram staining; followed by biochemical tests (Remel RapID ANA II test kit, USA). The isolates were quantified on blood agar to sort out pathogenic isolates from field cases of $C P$ related enterotoxaemia (Philippeau et al., 2003).

\section{DNA extraction}

Before DNA extraction, isolates were inoculated in Robertson cooked meat medium and incubated at $37^{\circ} \mathrm{C}$ for $12 \mathrm{~h}$ in shaking incubator. DNA was extracted according to the protocol of DNA extraction kit (GeneAll, South Korea). Obtained DNA was quantified using NanoDrop (Nano Drop, 2000, Thermo-Scientifics, Wilmington, DE 19810 USA) and stored at $-20{ }^{\circ} \mathrm{C}$.

\section{Confirmation of Clostridium perfringens by PCR}

Genotyping of $\mathrm{CP}$ was performed through PCR, targeting four major toxins $(\alpha, \beta, \varepsilon$, and $\imath)$, as described by Greco et al., (2005) in Table I. Briefly, the reaction was performed in a thermocycler (BIO RAD T 100) in $25 \mu \mathrm{L}$ volume, in micro amplification tubes (PCR tubes) containing 2XAmpmaster ${ }^{\text {TMTaq }}$ (Gene All Biotechnology CO. Ltd) $10 \mu \mathrm{L}$, forward and reverse primers $1.5 \mu \mathrm{L}$ each, template DNA $5 \mu \mathrm{L}$ and DNA free distilled water $7 \mu \mathrm{L}$. The amplification reactions consisted of 35 cycles, 5 minutes initial denaturation followed by 35 cycles; consisting of denaturation at $94^{\circ} \mathrm{C}$ for 60 seconds, annealing at $\left(\alpha=60^{\circ} \mathrm{C}\right.$, $\beta=64^{\circ} \mathrm{C}, \varepsilon=53.4^{\circ} \mathrm{C}, i=61^{\circ} \mathrm{C}$ ) for 30 seconds, extension at $72^{\circ} \mathrm{C}$ for 60 seconds and final extension at $72^{\circ} \mathrm{C} 5$ for minutes. The PCR products $(5 \mu \mathrm{L})$ along with DNA ladder of $1 \mathrm{~Kb}\left(\mathrm{Genesta}^{\mathrm{TM}}\right)$ and optimized positive and negative control were run on $1.5 \%$ agarose gel for electrophoresis. Ethidium bromide $(1.5 \mu \mathrm{g} / \mathrm{mL})$ was used for staining the gel before being photographed under UV light.

\section{Hematobiochemical analysis}

Six milli Liter blood samples each from infected and healthy Balkhi sheep were collected from the jugular vein using disposable syringes. The blood was transferred to two sterile vacutainers, one containing heparin. Total RBC, WBC, platelets count, hemoglobin levels, and PCV were analyzed through hematology analyzer (Beckman Coulter, USA) from heparin added blood. Heparin free coagulated blood was centrifuged at $1500 \mathrm{rpm}$ for 20 minutes to collect serum for biochemical analysis. Aspartate aminotransferase (AST) and alanine aminotransferase (ALT) were measured with spectrophotometer by using their test kits (Bio-Diagnostics, Cairo, Egypt) (Reitman and Frankel, 1975). Serum creatinine and urea were also measured by using their appropriate diagnostic kits (Human, Germany). Blood glucose level was measured directly on glucose strip (codefree ${ }^{\mathrm{TM}}$, Korea) and read with a Glucometer before the addition of anticoagulant.

\section{Statistical analysis}

Descriptive analysis was used to represent all parameters as mean \pm Standard Error. Two tail $t$-test at the level of $95 \%$ confidence interval $(\mathrm{P}<0.05)$ was used for hematobiochemical comparisons between diseased and healthy animals through SPSS 21.0 version statistical program.

\section{RESULTS}

\section{Clinical parameters}

Clinically infected sheep showed the signs of abdominal pain, mild to severe (blood-tinged to bloody) yellow pasty diarrhea, frothy salivation and varying degree of nervous signs. Clostridium perfringens infected sheep 
Table I. Primers used for PCR amplification of gene for $C$. perfringens toxins $\alpha, \beta, \varepsilon$ and i.

\begin{tabular}{lllc}
\hline Toxin/gene & Oligonucleotide sequence & Fragment length (bp) \\
\hline$\alpha / \mathrm{cpa}$ & 5-TGC TAA TGTTAC TGC CGT TGA TAG-3 & 247 & Daube et al. (1994) \\
& 5-TGC TAA TGTTAC TGC CGT TGA TAG-3 & & Kadra et al. (1999) \\
$\beta / \mathrm{cpb}$ & 5-AAC TTA ACT GGA TTT ATG TCT TCA-3 & 317 & Daube et al. (1994) \\
& 5-ATA GTA GAA AAA TCA GGT TGG ACA-3 & 206 & Daube et al. $(1994)$ \\
i/iap & 5-ATT AAA ATC ACA ATC ATT CAC TTG-3 & & 298 \\
\hline
\end{tabular}

Table II. Distributions of Clostridium perfringens types on the basis of the toxin genes from enterotoxemia infected Balkhi sheep.

\begin{tabular}{llll}
\hline $\begin{array}{l}\text { C. perfrin- } \\
\text { gens types }\end{array}$ & $\begin{array}{l}\text { Toxin genes of } \\
\text { C. perfringens }\end{array}$ & $\begin{array}{l}\text { Number } \\
\text { of isolates }\end{array}$ & $\begin{array}{l}\text { Percentage } \\
\text { of isolates }\end{array}$ \\
\hline A & Cpa & 57 & $53.27 \%$ \\
B & $c p a, c p b, e t x$ & 11 & $10.28 \%$ \\
C & $c p a, c p b$ & 0 & $0 \%$ \\
D & $c p a$, etx & 39 & $36.44 \%$ \\
E & $c p a$, iap & 0 & $0 \%$ \\
Total & & 107 & $100 \%$ \\
\hline
\end{tabular}

were dehydrated with pale mucous membranes and their mean body temperature was $40.1 \pm 0.21{ }^{\circ} \mathrm{C}$.

\section{Bacteriological parameters}

Growth of CP was identified as small black colonies on tryptose sulfite cycloserine agar media (HiMedia Laboratories pvt Ltd. India); identity was confirmed by Gram staining and biochemical testing panel results with test kit (remel-RapID ANA II system test kit, USA). Colony counts were quantified on blood agar and colony countsmore than 104-107 CFU/g were considered, as pathogenic. Balkhi sheep were only considered healthy when no growth was obtained on tryptose sulfite cycloserine agar media (Hi Media Laboratories pvt. Ltd. India) after 24 hours incubation at $37^{\circ} \mathrm{C}$ in anaerobic jar with $\mathrm{CO}_{2}$ packs. Out of 184 suspected sheep,107 (58.15\%) were identified infected with CP. Genotyping of 107 strains from infected sheep indicated 57(53.27\%) infected with CP type A, 11 (10.28\%) with type B and 39 (36.44\%) with type D by conventional PCR however no case of type $\mathrm{C}$ and type $\mathrm{E}$ were found (Table I).

\section{Hematobiochemical parameters}

Mean hemoglobin levels and erythrocyte counts
(RBC) decreased while the white blood cells (WBC), packed cell volume (PCV), platelet counts and total bilirubin increased significantly $(\mathrm{P}<0.05)$ in $\mathrm{CP}$ type $\mathrm{A}$ infected sheep (Tables III and IV). In CP type B and type D infected sheep mean erythrocytes count (RBC) and hemoglobin levels decreased while white blood cells (WBC), packed cell volume (PCV), platelets count, aspartate aminotransferase (AST), alanine aminotransferase (ALT), total bilirubin, serum creatinine, blood glucose and urea increased significantly $(\mathrm{P}<0.05)$. Fluctuations in mean hemoglobin level, erythrocyte counts (RBC), packed cell volume (PCV) and total bilirubin were beyond the normal limits while others were within normal ranges in CP type A infected sheep. Alanine Aminotransferase (ALT), total bilirubin, serum creatinine, blood urea and glucose were beyond the normal limits while others were within normal ranges in CP type B and type D infected sheep (Tables III and IV).

\section{DISCUSSION}

Clostridium perfringens is the normal occupant of the gastrointestinal tract in animals and people but turns pathogenic when gastrointestinal tract condition disturbed by sudden changes in feed, eating regimen or stasis in digestive system. The number of CP increases exponencially and production of distinctive toxins is increased many folds (Uzal, 1996). The sickness is associated with elevated amounts of toxins in the digestive system, with death of the animal or acute form of disease (Vaikosen and Ikhatua, 2005). Present study demonstrated $58.15 \%$ pathogenic isolates of $\mathrm{CP}$ from enterotoxemia suspected sheep. Out of them, 57 (53.27\%) were CP type A, no. (10.28\%) type B and no. (36.44\%) type D, types $\mathrm{C}$ and $\mathrm{E}$ were not diagnosed. Itodo et al. (1986) depicted the pervasiveness of $\mathrm{CP}$ writes A (22.05\%), type B (4.0\%) and type $\mathrm{D}(15.75 \%)$ in their examination in Nigeria. 
Table III: Haematological parameters (Mean \pm SE) of $C$. perfringens type A, B and D infected and healthy Balkhi sheep.

\begin{tabular}{|c|c|c|c|c|c|c|}
\hline \multirow[t]{2}{*}{ Parameters } & \multicolumn{2}{|c|}{ Type A } & \multicolumn{2}{|c|}{ Type B } & \multicolumn{2}{|c|}{ Type D } \\
\hline & Normal & Infected & Normal & Infected & Normal & Infected \\
\hline Hemoglobin (g/dL) & $9.81+0.15$ & $6.61+0.13 *$ & $10.03+0.15$ & $9.15+0.18$ & $9.81+0.17$ & $8.42+0.35^{*}$ \\
\hline $\operatorname{RBC}\left(10^{6} / \mu \mathrm{L}\right)$ & $11.47+0.15$ & $7.64+0.09 *$ & $11.45+0.19$ & $9.72+0.25^{*}$ & $11.47+0.15$ & $9.77+0.19^{*}$ \\
\hline $\mathrm{WBC}\left(10^{3} / \mu \mathrm{L}\right)$ & $17.40+0.43$ & $9.25+0.06^{*}$ & $9.15+0.03$ & $18.04+0.96^{*}$ & $9.39+0.09$ & $17.99+0.63 *$ \\
\hline Platelets $\left(10^{5} / \mu \mathrm{L}\right)$ & $5.33+0.09$ & $4.70+0.06^{*}$ & $4.63+.08$ & $5.35+0.10$ & $4.76+0.04$ & $5.32+0.09 *$ \\
\hline PCV\% & $45.89+0.29$ & $37.22+0.32$ & $37.89+0.45$ & $42.04+1.43$ & $37.21+0.37$ & $42.44+0.98^{*}$ \\
\hline
\end{tabular}

${ }^{1}$ Alanine Aminotransferase, ${ }^{2}$ Aspartate Aminotransferase; * at the value indicates the statistically significant difference between healthy and infected groups

Table IV: Biochemical parameters (Mean \pm SE) of $C$. perfringens type A, B and D infected and healthy Balkhi sheep.

\begin{tabular}{|c|c|c|c|c|c|c|}
\hline \multirow[t]{2}{*}{ Parameters } & \multicolumn{2}{|c|}{ Type A } & \multicolumn{2}{|c|}{ Type B } & \multicolumn{2}{|c|}{ Type D } \\
\hline & Healthy & Infected & Healthy & Infected & Healthy & Infected \\
\hline $\operatorname{ALT}^{1}(\mathrm{U} / \mathrm{L})$ & $33.77+87$ & $17.51+0.45^{*}$ & $14.76+0.13$ & $37.97+0.67 *$ & $14.51+0.18$ & $38.52+0.59 *$ \\
\hline $\mathrm{AST}^{2}(\mathrm{U} / \mathrm{L})$ & $58.28+1.76$ & $30.35+1.51^{*}$ & $27.36+0.77$ & $78.73+0.81 *$ & $27.21+0.87$ & $78.83+1.50^{*}$ \\
\hline Total bilirubin (mg/dL) & $4.94+0.18$ & $0.37+0.03 *$ & $0.37+0.02$ & $4.48+0.21^{*}$ & $0.31+.03$ & $4.49+0.13 *$ \\
\hline Blood glucose (mg/dL) & $70.03+1.97$ & $67.7+0.69 *$ & $67.57+0.73$ & $134.55+3.67 *$ & $67.70+0.69$ & $130.51+4.26^{*}$ \\
\hline Urea $(\mathrm{mg} / \mathrm{dL})$ & $20.71+0.88$ & $19.6+0.59 *$ & $19.69+0.42$ & $66.49+1.51^{*}$ & $19.60+0.50$ & $70.11+3.11^{*}$ \\
\hline Creatinine (mg/dL) & $1.66+0.07$ & $1.57+0.08^{*}$ & $1.50+0.04$ & $5.66+0.26^{*}$ & $1.50+0.05$ & $5.80+0.23 *$ \\
\hline
\end{tabular}

${ }^{1}$ Alanine Aminotransferase, ${ }^{2}$ Aspartate Aminotransferase; * at the value indicates the statistically significant difference between healthy and infected groups.

Their outcome demonstrated the presence of CP type A (40.62\%), type B (3.125\%), type C was $(28.125 \%)$ and type D $(28.125 \%)$. A few examinations conducted in different countries revealed the most predominant type A in sheep (Itodo et al., 1986; Efuntoye and Adetosoye, 2003). It is a typical view that CP types $B, C$, and $D$ have major part of enterotoxaemia, while CP type A alone is not included or has extremely constrained impact. As of late, a few analysts have given an account of the significance of CP type A (Manteca et al., 2001). Greco et al. (2005) revealed that $\mathrm{CP}$ types $\mathrm{A}$ and $\mathrm{D}$ were recognized, $84 \%$ and $16 \%$ by PCR, in 87 sheep and 15 kids.

Results of our study have indicated pronounced anemia because of diminished erythrocyte check and decreased hemoglobin level while increase in leukocyte count, platelets count, and packed cell volume expanded in all CP type A, B and D infection in sheep when compared with sound sheep. Comparative discoveries were accounted for by Hassanein et al. (2017) in Egypt. In another study Nasir et al. (2013) reported similar findings following the experimental CP type D disease in sheep. Alpha toxin is phospholyphase having hemolytic and necrotizing while epsilon is lethal in nature (Quinn et al., 2004; Fatmawati et al., 2013). Comparable perceptions were noted by Smith (1975) in his investigation demonstrating the rise of acid soluble phosphate are because of alpha toxin. Alpha toxin hydrolyzes the phospholipids in the cell film of RBC's, causing its lysis. Our findings were supported by the findings of Ombe et al. (2006) who detailed that the presence of toxin restricting receptors on the surface of erythrocytes of different species is related with hemolysis. The alpha toxin likewise causes the lysis of leukocytes and platelets. This may be because of a similar mechanism, like RBC hemolysis. The increase in white platelets is considered as a guide in diagnosing the enterotoxemia in living organisms (Smith and Sherman, 1994; Dennis and Bryant, 2002), same results are obtained in present study. Clostridium chauvoei hemolysins receptors exist on RBSs surfaces in different species, examined by Ombe et al. (2006) additionally supported our findings. Increase in WBCs and platelets can help as supportive in the diagnosis of enterotoxaemia (Smith and Sherman, 1994; Dennis and Bryan, 2002). Increase in packed cell volume was because of lack of hydration which was noted in all infected sheep.

In our results mean AST, ALT and bilirubin increased significantly $(\mathrm{p}<0.05)$ in CP type A infected sheep while 
the mean AST, ALT add up to bilirubin, serum creatinine, blood glucose and urea levels increased significantly $(\mathrm{p}<0.05)$ in both CP type B and D infected sheep. Our outcomes were strengthened by Radostitis et al. (2007), Hassanein et al. (2017) who have reported fluctuation in liver enzymes and bilirubin because of harm in hepatic tissue in enterotoxaemia. Hyperglycemia is steady analysis of enterotoxemia (Radostitis et al., 2007; Filho et al., 2009) which strengthened our findings. Alpha toxins are necrotizing in nature which are found in all CP type A, type B and type D infections causes damages of veins, liver and hemolysis (OIE, 2004). Mylashiro et al. (2007) showed that epsilon toxin produces renal and liver damages, gastroenteritis, and systemic hemorrhage in various organs upheld our results of expanded liver and kidneys enzymes are because of the harms created in these organs. Epsilon toxin of CP causes harms in the kidneys (Miyakawa et al., 2007; El-Ghareib and Amer, 2009; ElSify et al., 2016). Clostridium perfringens causes renal damage, which brings about serum creatinine and blood urea increase. The activity of CP toxin on kidneys particularly the epsilon toxin has likewise been exhibited by different researchers (Miyakawa et al., 2007; Heba et al., 2009).

\section{CONCLUSION}

All in all, the hematological and biochemical parameters varied significantly in all CP type A, B and D. however. the vast majority of these stayed within the normal range. Mean RBC counts, hemoglobin level, PCV and total bilirubin fluctuated beyond the normal limits in CP type A infected sheep while liver enzyme, total bilirubin, serum creatinine, blood urea and glucose levels fluctuated beyond the normal limits in CP type B and D infected sheep.

\section{ACKNOWLEDGEMENT}

We are exceptionally grateful to Veterinary Research Institute, Peshawar and Department of Animal Health, The University of Agriculture, Peshawar for their specialized and Lab. Support.

\section{Statement of conflict of interest}

All authors declare no conflict of interest.

\section{REFERENCES}

Baums, C.G., Schotte, U., Amtsberg G. and Goethe R., 2004. Diagnostic multiplex PCR for toxin genotyping of Clostridium perfringens isolates. Vet.
Microbiol., 100: 11-16. https://doi.org/10.1016/ S0378-1135(03)00126-3

Dennis, L.S. and Bryant B., 2002. The role of clostridial toxins in the pathogenesis of gas gangrene. Clinic. Infec. Dis., 35: 93-100. https://doi. org/10.1086/341928

Efuntoye, M.O. and Adetosoye, A.I., 2003. Clostridial diarrhea in food animals in Ibadan, Nigeria. Israel Vet. med. Assoc., 58: 1-4.

El-Ghareib, H.H. and Amer, H.A.M., 2009. Pathological and bacteriological studies on Clostridium perfringens infection in kidney of cattle, camel and sheep. Egypt. J. comp. Path. clinic. Path., 22: 88-108.

ElSify, A., Tarabess, R., Nayel, M.A., Salma, A., Allaam, M., Abd El-Gaber, M., Hassan, H., Zaghawa, A. and Elballal, S., 2016. Bacteriological and molecular studies on Clostridium perfringens isolated from sheep in three Egyptian provinces. Afr. J. microbiol. Res., 10: 725-732. https://doi. org/10.5897/AJMR2016.8023

Fernandez, M.E. and Uzal, F.A., 2003. The early effects of Clostridium perfringens type D epsilon toxin in ligated intestinal loops of goat and sheep. Vet. Res. Commun., 27: 231-241.

Filho, E.J.F., Carvalho, A.U., Assis, A.R., Lobato, F.F., Rachid, M.A., Carvaho, A.A., Ferreira, P.M., Nascimen, R.A., Fernandes, A.A., Vidal, J.E. and Uzal, F.A., 2009. Clinicopathologic features of experimental Clostridium perfringens type D enterotoxaemia in cattle. Vet. Pathol., 46: 12131220. https://doi.org/10.1354/vp.08-VP-0304-UFL

Fatmawati, N.N., Sakaguchi, Y., Suzuki, T., Oda, M., Shimizu, K., Yamamoto, Y., Sakurai, J., Matsushita, O. and Oguma, K., 2013. Phospholipase C produced by Clostridium botulinum types $\mathrm{C}$ and $\mathrm{D}$ : comparison of gene, enzymatic, and biological activities with those of Clostridium perfringens alpha-toxin. Acta med. Okayama, 67: 9-18.

Gkiourtzidis, K., Frey, J., Bourtzi-Hatzopoulou, E., Iliadis, N. and Sarris, K., 2001. PCR detection and prevalence of a, b, b2, e, i, and enterotoxin genes in Clostridium perfringens isolated from lambs with clostridial dysentery. Vet. Microbiol., 82: 39-43. https://doi.org/10.1016/S0378-1135(01)00327-3

Greco, G., Madio, A., Buonavoglia, D., Totaro, M., Corrente, M., Martella, V. and Buonavoglia, C., 2005. Clostridium perfringens toxin-types in lambs and kids affected with gastroenteric pathologies in Italy. Vet. J., 170: 346-350. https:// doi.org/10.1016/j.tvj1.2004.08.001 
Heba, H., Ghareib, E.L. and Amer, H.A.M., 2009. Pathological and bacteriological studies on Clostridium perfringens infection in kidney of cattle, camel and sheep. Egypt. J. comp. clinic. Path., 22: 88 - 108.

Hadimli, H.H., Erganis, O., Sayn, Z. and Aras, Z., 2012. Toxinotyping of Clostridium perfringens isolates by ELISA andPCR from lambs suspected of enterotoxemia. Turk. J. Vet. Anim. Sci., 36: 409415.

Hassanein, K.M.A., Sayed, M.M. and Hassan, A.M., 2017. Pathological and biochemical studies on enterotoxemia in sheep. Comp. clin. Pathol., 26: 513-518. https://doi.org/10.1007/s00580-0172407-5

Itodo, A.E., Adesiyun, A.A., Adekeye, J.O. and Umoh, J.U., 1986. Toxin types of Clostridium perfringens strain isolated from sheep, cattle and paddock soils in Nigeria. Vet. Microbiol., 12: 93-96. https://doi. org/10.1016/0378-1135(86)90045-3

Javed, M.T., Irfan, M., Mukhtar, N., Rahman, S. and Hussain, R., 2009. An outbreak of enterotoxaemia at livestock farm during subtropical summer. Acta Trop., 11: 225-227. https://doi.org/10.1016/j. actatropica.2009.07.003

Khan, A., Ali, I., Hussain, I. and Ahmad, N., 2008. Clostridium perfringens type D enterotoxaemia in the Chinkara Deer (Gazella bennettii). Turk. J. Vet. Anim. Sci., 32: 225-228.

Lewis, C.J., 2000. Clostridial diseases. In: Diseases of sheep (eds. W.B. Martin, I.D. Aitken). Blackwell Science, Oxford.

Manteca, C., Daube, G., Pirson, V., Limbourg, B., Kaeckenbeeck, A. and Mainil, J.G., 2001. Bacterial intestinal flora associated with enterotoxaemia in Belgian Blue calves. Vet. Microbiol., 81: 21-32. https://doi.org/10.1016/S0378-1135(01)00329-7

Miyakawa, M.E.F., Derek, J.F., Poon, R., Sayeed, S., Adams, V., Rood, J.I., McClane, B.A. and Uzal F.A., 2007. Both epsilon-toxin and beta-toxin are important for the lethal properties of Clostridium perfringens type $\mathrm{B}$ isolates in the mouse intravenous injection model. Infec. Immun., 75: 1443-1452. https://doi.org/10.1128/IAI.01672-06

Mylashiro, S., Nassar, A.F.C., Delfava, C., Carbal, A.D., Renom, J. and Silva, M., 2007. Clostridium perfringens type $\mathrm{A}$ and $\mathrm{D}$ associated with enterotoxemia in an 18-month-old goat. J. Venom. Anim. Toxins. Incl. Trop. Dis., 13: 885-893. https:// doi.org/10.1590/S1678-91992007000400017

Ma, M., Vidal, J., Saputo, J., McClane, B.A. and Uzal, F.A., 2011. The VirS/VirR two component system regulates the anaerobic cytotoxicity, intestinal pathogenicity, and enterotoxemic lethality of Clostridium perfringens type C isolates CN3685. MBio., 2: $338-10$. https://doi.org/10.1128/ mBio.00338-10

Nasir, A.A., Younus, M., Rehman, M.U., Lateef, M., Khaliq, S.A., Ahmad, I. and Abbas, M., 2013. Hematological and some biochemical alterationsin sheep experimentally infected with Clostridium perfringens type D infection. J. Anim. Pl. Sci., 23: 1553-1558.

Nayel, M.A., ElSify, A., Akram, S., Allaam, M., Abdeenb, E. and Hassan, H., 2013. Molecular typing of Clostridium perfringensisolates from soil, healthy, and diseased sheep in Egypt by multiplex PCR. Beni-Suef Vet. med. J., 22: 53-57.

OIE, 2004. BOIE institute for international cooperation in animal biologies an OIE collaborating center. Iowa State University College of Veterinary Medicine.

Ombe, B.M.H., Kohda, T., Mukamoto, M. and Kozaki, S., 2006. Purfication and sensitivity of Clostridium chauvoei hemolysin to various erythrocytes. Comp. Immunol. Microbiol. Infect. Dis., 29: 263-268. https://doi.org/10.1016/j.cimid.2006.06.002

Philippeau, C., Gonçalves, S. and Julliand, V., 2003. Mortssubites des bovins-diagnostic bactériologiques des entérotoxémies. Le. Point. Vét., 237: 12-13.

Quinn, P.J., Carter, M.A., Markey, B. and Carter, G.R., 2004. Clinical veterinary microbiology. pp. 191208.

Reitman, S. and Frankel, S., 1975. Glutamic-pyruvate transaminase assay by colorimetric method. Am. J. clin. Pathol., 28: 56. https://doi.org/10.1093/ ajcp/28.1.56

Radostits, O.M., Gay, C.C., Hinchcliff, K.W. and Constable, P.D., 2007. Veterinary medicine: a textbook of the diseases of cattle, sheep, goats, pigs, and horses, $10^{\text {th }}$ edn. Saunders, Philadelphia, pp. 834-836.

Smith, L.D.S., 1975. The pathogenic anaerobic bacteria . $2^{\text {nd }}$ Ed. Charles C. Thomas. Springfield. IL.

Smith, M.C. and Sherman, D.M., 1994. Goat medicine. Lippincott, $2^{\text {nd }} \mathrm{Ed}$. Williams and Wilkins, Baltimore: pp. 298-302.

Tahir, M.F., Mahmood, MS. and Hussain, I., 2013. Preparation and comparative evaluation of different adjuvanted toxoid vaccines against enterotoxaemia. Pak. J. agric. Sci., 50: 293-297.

Uzal, F.A., 1996. Diagnosis of Clostridium perfringens intestinal infections in sheep and goats. 
Anaerobe, 10: 135-143. https://doi.org/10.1016/j. anaerobe.2003.08.005

Uzal, F.A. and Songer, J.G., 2008. Diagnosis of Clostridium Perfringens intestinal infections in sheep and goat. J. Vet. Diagn. Invest., 20: 253-265. https://doi.org/10.1177/104063870802000301

Uzal, F.A., Vidal, J.E., McClane, B.A. and Guraj, A.A., 2014. Clostridium perfringenstoxins involved in mammalian veterinary diseases. J. Toxicol., 2: 2442. https://doi.org/10.2174/1875414701003010024 Vaikosen, E.S. and Ikhatua, U.J., 2005. Detection of high level of enterotoxin of Clostridum perfringens types $C$ and D in small ruminants in Nigeria. Small. Rum. Res., 58: 287-290. https://doi.org/10.1016/j. smallrumres.2004.11.004 